\title{
TUMAČENJE STUDENTSKIH STAVOVA O RELIGIJI U ODNOSU NA KURSEVE DEPARTMANA
}

Rezime: Deo projekta Departmana za filozofiju jednim svojim delom ticao se ispitivanja studentskih stavova o religiji i transcendentnim entitetima. Paralelno sa praćenjem ovih stavova pokuašno je i praćenje promena u njima tokom dva semestra, te je ovaj tekst prikaz i analiza promena koje su se desile ili izostale, s konačnim ciljem da se uvidi da li su i u kojoj meri kursevi na OAS koji se bave pomenutim pitanjima mogli da utiču na promene u stavovima studenata.

Ključne reči: stavovi studenata, religija, Bog, duša.

\section{Uvod}

Cilj ovog istraživanja bio je da se ispita uticaj kurseva filozofije na promenu stavova o religiji, dakle, određenog znanja, koje bi dovelo do izvesnih pomeranja stavova. Opšte je poznato da se stavovi jako teško menjanju, te da na njihovo formiranje ili promenu utiče puno faktora, tako da i ovo istraživanje treba shvatiti uslovno, što znači da ono može ponuditi određene pretpostavke, ali svakako ne i sigurne rezultate.

Najpre treba naglasiti da je krajnji validni uzorak testiranih studenata veoma mali u odnosu na ukupan broj istih. Ovaj problem nastao je kao posledica toga što mnogi nisu sračunali početnu šifru kako treba, nisu zaokruživali godinu studija i pol. Neočekivano najveći problem tu je ipak potekao od šifre, s obzirom da je ona parametar po kome se jedan ispitanik prati kroz semestre. Sve ovo rezultovalo je ukupnim brojem od 22 studenta $(6+8+3+5)$ sa sve četiri godine koji predstavljaju konačan materijal za analizu.

Testiranu grupu činile su sve četiri godine osnovnih studija. Identični testovi prilagođeni svakoj godini davani su na početku prvog i na kraju drugog semestra. Ta dinamika osmišljena je zbog toga što bi prvi test trebalo da predstavlja ,sirove” intuicije studenata pre slušanja kurseva za koje su testirani, a potom i eventualne promene koje su nastale nakon jedne godine studija. Metod analize prikupljenih podataka za koji smo se odlučile je kvantitativno i kvalitativno praćenje promena na osnovu kvantitativno prikazanih podataka. Skala po kojoj je neko mogao da se opredeli za svoje stavove bila je od 1 do 5, gde je 1 - uopšte se ne slažem, 2 -većinom se ne slažem, 3 - nisam siguran/-na, 4-većinom se slažem, 5 - u potpunosti se slažem. U nastavku se može videti tabela sa unetim i analiziranim podacima koja sadrži pitanja iz oblasti religije, kao i klasifikaciju prema godinama studija. Na kraju svake godine 
računate su razlike u oscilacijama među stavovima, dok su crveni brojevi oznake korišćene za razliku u promeni. 0 označava da nema promene, bilo koji pozitivni broj približavanje slaganju na skali, a bilo koji negativan broj odstupanje, odnosno udaljavanje od stava iznesenog u prethodnom semestru.

Ono što je ključno naglasiti je da svi tumačeni rezultati nužno počivaju na spekulaciji i ne mogu pokazati konkluzivne stavove. Takođe, trenutnom analizom podataka obuhvatićemo samo jedan, prvi i donekle najvidljiviji, deo moguće analize na osnovu datih parametara.

\section{Rezultati}

Opšte je poznato da se stavovi teško menjaju, te da na njihovo formiranje ili promenu utiče puno faktora, tako da i ovo istraživanje treba shvatiti uslovno, dakle, ono može ponuditi određene pretpostavke, ali svakako ne i sigurne rezultate.

Kroz kraću analizu preko datih tabela može se doći do određenih načelnih uvida, najpre o opštim stavovima studenata filozofije o religiji, a zatim i o tome ima li promene tih stavova u toku jedne školske godine. Ono što se može videti jeste da studenti filozofije ne smatraju da Bog postoji kao natčulni entitet, ali prihvataju religiju kao određeni društveni i kulturološki fenomen. S druge strane, ne vode se mišljenjem da je religija nužno povezana sa slobodnom voljom, moralom i obrazovanošću. Kod većine tema nije došlo do bitnih promena stavova posle odslušanih kurseva filozofije, ali postoje i teme gde je do toga došlo, a one se uglavnom odnose na probleme koji zahtevaju veći stepen logičkog i kritičkog promišljanja. U svakom slučaju tamo gde je došlo do promena mišljenja, to se obično nije desilo u jednom smeru, nego je promena mišljenja zabeležena u oba pravca. Ovo govori u prilog činjenici da se studenti filozofije čak i kada menjaju stavove ne povode za nekim trendom, nego imaju kritički pristup prema zadatim temama iz religije. Pri tome treba napomenuti da studenti filozofije na Departmanu za filozofiju u Nišu dolaze u dodir sa religioznom tematikom najviše iz predmeta koji se bave istorijom filozofije (posebno tu treba naglasiti Istoriju antičke, srednjevekovne i novovekovne filozofije) i Filozofije religije, ali da na promenu njihovih stavova utiču i sadržaji sa drugih kurseva filozofije, te i način na koji se ta znanja tokom godina studija međusobno kombinuju u svakom pojedincu. 


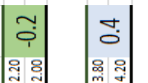

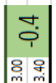

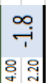

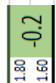

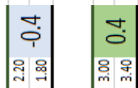

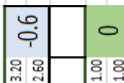
$\left|\begin{array}{c}0 \\ i \\ i \\ \hdashline \\ \hdashline\end{array}\right|$

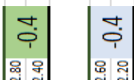

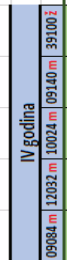

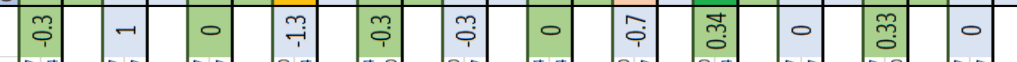

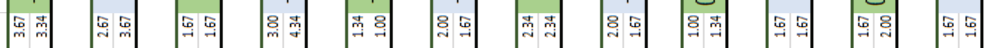

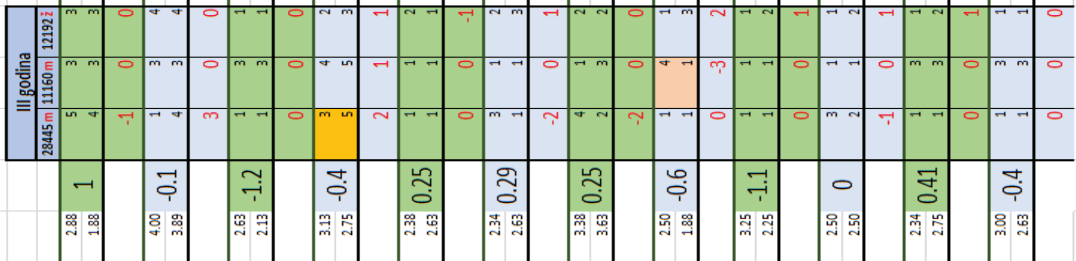

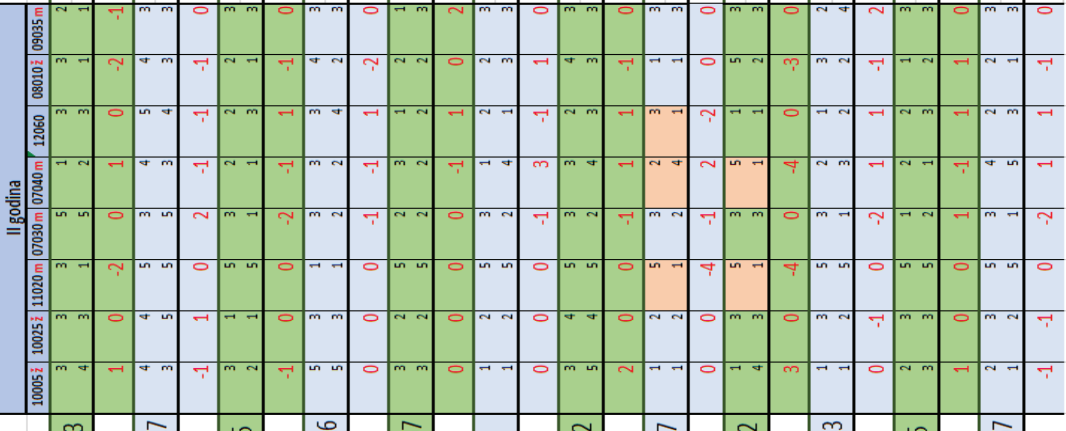

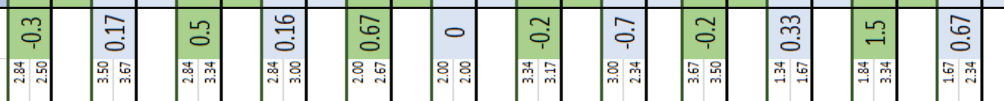

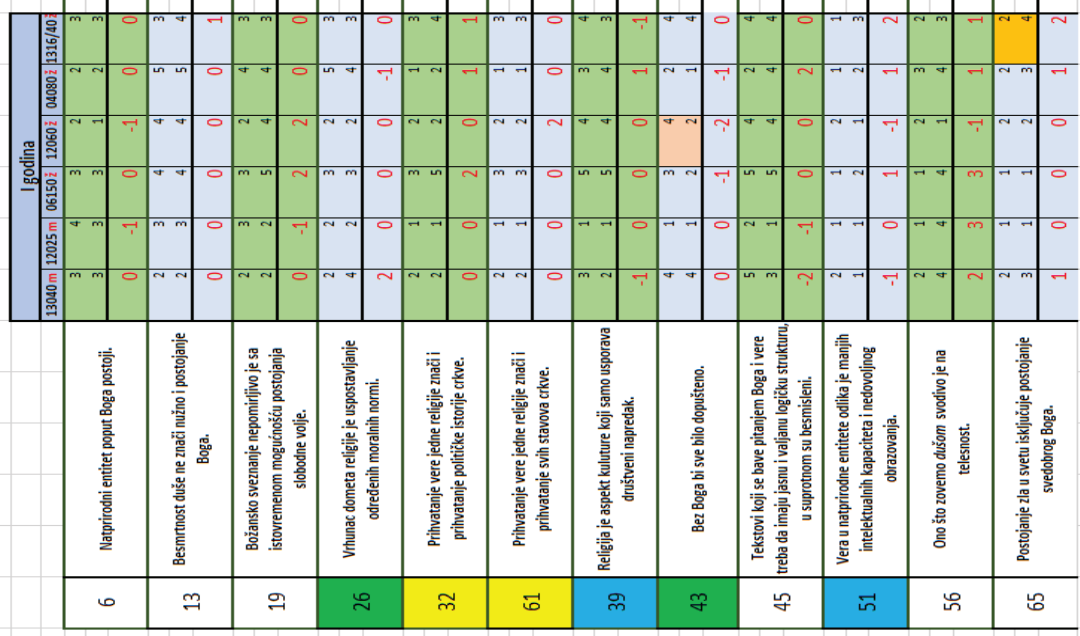

Slika 1 - tabela sa analiziranim podacima 


\section{Analiza}

1. Pitanja počinju od toga da li se uopšte veruje u postojanje natprirodnog entiteta poput Boga $(6)^{1}$, da bi se kretala sledećim tokom:

2. (13) Besmrtnost duše ne znači nužno i postojanje Boga.

3. (19) Božansko sveznanje nepomirljivo je sa istovremenim postojanjem slobodne volje.

4. (26) Vrhunac dometa religije je uspostavljanje određenih moralnih normi.

5. (32) Prihvatanje vere jedne religije znači i prihvatanje političke istorije crkve.

6. (61) Prihvatanje vere jedne religije znači i prihvatanje svih stavova crkve.

7. (39) Religija je aspekt kulture koji samo usporava društveni napredak.

8. (43) Bez Boga bi sve bilo dopušteno.

9. (45) Tekstovi koji se bave pitanjem Boga i vere treba da imaju jasnu i valjanu logičku strukturu, u suprotnom su besmisleni.

10. (51) Vera u natprirodne entitete odlika je manjih intelektualnih kapaciteta i nedovoljnog obrazovanja.

11. (56) Ono što zovemo dušom svodivo je na telesnost.

12. (65) Postojanje zla u svetu isključuje postojanje svedobrog Boga.

Iz priloženog se može videti da se pitanja formirana ka odnosu prema Bogu ili intelignentnom kreatoru kreću od odnosa besmrtnosti duše i njene zavisnosti od takvog entiteta, duše i njene potencijalne telesnosti, preko pitanja postojanja zla pod pretpostavkom da je božanski entitet svedobar, pitanja omniscijentnosti i slobodne volje, kao i preko nekoliko istorijsko-etičkih pitanja koja se bave time da li bi se moglo govoriti o postojanju moralnosti bez postojanja sveprožimajuće omniinteligencije poput Boga, kao i da li religija možda u svom vrhuncu služi samo uspostavljanju određenih moralnih normi. Zatim, postavljaju se i pitanja da li prihvatanjem veroispovesti određene religije pojedinac prihvata i sve stavove institucije te religije, kao i da li prihvata političku stranu takve istorije. Na kraju, testirane su bile i vrlo česte intuicije, poput onih koje impliciraju da su religiozni pojedinci oni manjeg intelekta i obrazovanja, kao i da li religija samo usporava društveni napredak.

Idući otpočetka, 13 testiranih nema definisane stavove o postojanju Boga, troje naginje ka tome da takav entitet ne postoji, dok dvoje kategorički odbija takvo postojanje. Samo 2 studenta izjašnjavaju se nesumnjivo za postojanje, dok jedan naginje ka tome da postoji. U drugom semestru je nešto drugačija situacija, gde je 10 neutralnih, isti broj onih koji naginju ka nepostojanju, ali 6 onih koji ne veruju u božansko postojanje. Broj onih koji se kategorički izražavaju u prilog postojanja sada je spao na 1, a na račun toga se za 1 povećao broj onih koji su zaokružili opciju 4.

Interesantno je primetiti da većina studenata statistički naginje ka stavu da besmrtnost duše ne mora biti povezana sa postojanjem Boga, a to se nešto više može iščitati kod studenata koji su neutralni, odnosno neverujući. Kada smo u domenu govora o duši, još jasnije se vidi da je mali broj onih koji bi dušu sveli na nešto telesno,

\footnotetext{
${ }^{1} \mathrm{U}$ zagradi su brojevi ovih pitanja kako su se našla u testu.
} 
nezavisno od svojih religioznih uverenja. Po tom pitanju se najveći skok u promeni stavova i prosvođenju na telesnost beleži u drugom semestru prve godine. Ovome se možda može pripisati određeno gradivo iz predmeta Uvod u filozofiju, koje se bavi odnosom fizikalizma i suprotstavljenih stanovišta, kao i možda detaljnija diskusija o duši pri obradi dijaloga Fedon iz Istorije antičke filozofije, ali ostajemo bez daljih potvrda za ovako nešto.

Možda statistički najmanje oscilacija može da se prati po pitanju odnosa postojanja zla i svedobrog Boga. 12 studenata nije menjalo svoje stavove kroz dva semestra, od čega 6 uopšte ne zastupa to da postojanje zla isključuje postojanje svedobrog Boga. Samo jedna osoba je na suprotnom kraju skale, dok je većina ostalih kolebljiva između opcija 2 i 3.

Donekle očekivani rezultati koji se prate kroz oscilacije od 2 ili -2 stava razlike sreću se kod studentima večito interesantnog i nepresušnog pitanja o postojanju slobodne volje koje se kosi ili ne kosi sa postojanjem sveznajućeg Boga. Još interesantnije je da se najveće promene mogu očitati kod studenata 4. godine, gde je najčešći prelaz od toga da se većinom ne slažu da se ova dva fenomena isključuju do toga da se većinom slažu. Ipak, kod ovog pitanja postoji i jedna trivijalna, premda opravdana dilema da li su studenti mahinalno tokom popunjavanja testa zaboravili oznake brojeva, ili ih nesvesno permutovali, što ostaje opcija bez mogućnosti da se dalje istraži. Takođe, postoji i mogućnost da je kolebanje realistično prikazano u ovom rasponu i svesno birano, s obzirom na prirodu mogućeg promišljanja na ovu temu, kao i količine znanja koja bi trebalo da očekivano raste sa godinom studija. Slično se dešava i sa nekim drugim pitanjima i takvi momenti obeleženi su roze bojom. Slične promene se dešavaju i na 1. godini, a nešto manje na 2. Ipak, na poslednjepomenutoj je najveći broj testiranih studenata po godini inače, dodatno onih koji su za po jedan stepen odmakli od ideje da su besmrtnost duše i sveznanje Boga, te odatle i kvantitativno najveće prosečno odstupanje.

Kada smo kod tekstova koji se bave pitanjem Boga i vere, vrlo interesantan rezultat desio se među ispitanicima sa 4. godine, gde se svi kroz oba semestra nepokolebljivo drže opcije 1, odnosno one koja implicira potpuno neslaganje sa tezom da su tekstovi na ovu temu besmisleni ukoliko nemaju jasnu i valjanu logičku strukturu (obeleženo zelenom bojom). Sa jednom promenom u opciju 2 u drugom semestru, vrlo slična situacija je i na 3. godini. Znatno različitiji rezultati dobijeni su u 1. i 2. godini. Statistika pokazuje da su oscilacije većinom između opcija 4 i 5, s tim što se čini da je znatno bitnije posmatrati kako puno su se stavovi promenili u pojedincima. Četiri osobe na 2. godini su za 3 ili 4 stepena promenile svoje mišljenje. Kod onih koji su u jednom semestru zaokruživali 1 , a u drugom 5 , ostaje ista dilema kao i za neka pređašnja pitanja - da kojim slučajem nije došlo do nesvesne permutacije, ali je zanimljivo da ima i onih za koje je, sudeći po izabranim opcijama, manje upitno da su promenili svoje stavove. Ovde je bitno naglasiti da je 2. godina ona na kojoj se u oba semestra sluša predmet Istorija srednjevekovne filozofije koji je, imajući na umu period, obeležen religioznom hrišćanskom misli, te su veće promene u stavovima između dva semestra očekivane. Takođe, kao izborni predmet na Departmanu za sociologiju postoje Religije savremenog sveta, te treba uzeti u obzir da su oni 
studenti 2. godine koji su birali ovaj predmet bili izloženi ovim pitanjima dvostruko, premda na drugačiji način. Ipak, ostaje pitanje za neku posebnu studiju mogu li se ovde pratiti uticaji i njihove međusobne razlike. Posmatrajući rezultate za prve dve godine, još treba napomenuti da je birano više nižih ocena na skali u drugom semestru, što znači da su se tada prosečno studenti više opredeljivali za to da tekstovi koji se bave pitanjem Boga i vere ne treba da nužno imaju jasnu i valjanu logičku formu da bi bili smisleni.

Šest preostalih pitanja podeljena su u tri para, imajući u vidu to da je verovatno delotvornije rezultate uporediti i na ovaj način. Na taj korak sam se odlučila zbog toga što, iako su pitanja bila izmešana i protkana među pitanja iz nekih drugih filozofskih oblasti u testu, ne znači da se ne mogu smisleno povezati i takođe zbog toga što to možda može biti indikator za to koliko studenti jesu ili nisu razumeli šta se u pitanju pita, što opet jeste jedan aspekt testiranja intuicija.

Tako, što se tiče jednog od stereotipnih pitanja, da li je vera u natprirodne entitete samo odlika manjeg intelekta i obrazovanja, 12 studenata odgovorilo je opcijom 1, od čega je četvoro zadržalo isti stav i u drugom semestru, petoro je izabralo opciju 2, dok je preostalo troje od pomenutih 12 raspodelilo opcije 3, 4 i 5. Nedoumica je kod jednog studenta 4. godine (obeleženo roze bojom) da li je možda greškom zaokružena opcija 5, s obzirom na to da je u prvom semestru birana opcija 1 . Ostalih 10 studenata je prosečnog stava da ili se u najvećoj meri ne identifikuje sa ovih stavom (opcija 2), ili je neutralno. Samo jedan student sa 2. godine misli potpuno suprotno (5/5). Paralelno, rezultati za pitanje 39 nešto su ,šareniji” nego za prethodno, te se čini da je nešto više onih koji bi se saglasili sa ovom tvrdnjom. Ovo je vrlo moguć rezultat, s obzirom na to da se prosečno kroz rad sa studentima često susreće baš ovakav odnos između pomenuta dva pitanja.

Za parove pitanja 32 i 61 se čini da postoji određena kvalitativna paralela među stavovima crkve i političke istorije crkve, gde je većina naklonjena tome da se prilikom veroispovedanja jedne vere ne moraju nužno pirhvatiti ni jedno ni drugo. Od ovoga odstupaju samo dva studenta, jedan sa 2. jedan sa 4 . godine.

Poslednji par pitanja (26 i 43) pita da li je vrhunac dometa religije uspostavljanje moralnih normi i da li bi bez Boga sve bilo dopušteno. Što se prvog tiče, izgleda da je dosta stavova u rasponu između 2. i 4. opcije, gde je često jedan od stavova neutralan u jednom, da bi prevagao na jednu ili drugu stranu u onom drugom semestru. Što se drugog u paru tiče, na osnovu celokupnog uvida u rezultate povodom religije, pomalo iznenađuje to da je solidan broj onih koji su se minimum $u$ jednom od semestara opredelili za opciju 4, u dva slučaja čak i 5. Ipak, za oba ova pitanja ostaje upitno, kao što se može videti obeleženo u tabeli, koliko nije došlo do neke trivijalne greške. Ukoliko nije greška u pitanju, ostaje neuporedivo zanimljivo kao činjenica, ali isto tako i vrlo teško za analizu koji su sve faktori uticali na ovakva različita opredeljenja po jednoj osobi u dva semestra. 


\title{
Zaključak
}

Studenti filozofije se sa metafizičkim, ontološkim i religioznim pitanjima susreću konstantno u nekoj meri tokom svojih studija. Najeksplicitnije je to slučaj sa Istorijom srednjevekovne filozofije, Filozofijom religije, Ontologijom, ali se ne može reći da se ovakve teme ne mogu u određenoj meri susresti i na Uvodu u filozofiju, kao i etičkim i drugim predmetima. Svakako, ne treba izostaviti i pojedine izborne predmete sa nematičkih grupa koji sopstvenom prizmom i metodologijom dotiču ova pitanja. Ovakvi rezultati svakako su produkt svega toga, ali i jedinstvenosti pojedinca i njegovih životnih okolnosti. Zbog svega toga, da bi se nešto validnije moglo pratiti sa ovako osmišljenog projekta, potrebno je da on traje minimum četiri godine, ne bi li se mogla pratiti makar jedna cela generacija i svi studenti koji iz jedne generacije završe svoje studije. Ova analiza se stoga bavi preliminarnom obradom svih pitanja iz date oblasti, a svi detaljniji rezultati se moraju još studioznije i partikularnije proučavati ne bi li se uočile neke konkretnije promene i smanjio nivo spekulacije $u$ većoj meri.

\section{THE INTERPRETATION OF STUDENTS` OPINION ON RELIGION IN RELATION TO THE DEPARTMENT'S COURSES}

\begin{abstract}
Part of the Department of Philosophy's Project concerned the inquiry into the students' attitudes towards religion and transcendent entities. Parallelly with tracking these stands comes the attempt of tracking the changes that occured over the period of two semestres. Therefore, this article represents both a review and an analysis of either occurence or absence of changes, with the final aim of verifying whether and to what extent the relevant BA courses dealing with the mentioned topics could influence the formation of changes in the students' attitudes.
\end{abstract}

Key words: student attitude, religion, God, soul. 